\title{
Lumen
}

Selected Proceedings from the Canadian Society for Eighteenth-Century Studies

\section{Musical Nationalism and the Vauxhall Gardens}

\section{Paul F. Rice}

Volume 19, 2000

Material Productions \& Cultural Construction

Culture matérielle \& Constructions discursives

URI : https://id.erudit.org/iderudit/1012316ar

DOI : https://doi.org/10.7202/1012316ar

Aller au sommaire du numéro

Éditeur(s)

Canadian Society for Eighteenth-Century Studies / Société canadienne d'étude du dix-huitième siècle

\section{ISSN}

1209-3696 (imprimé)

1927-8284 (numérique)

Découvrir la revue

Citer cet article

Rice, P. F. (2000). Musical Nationalism and the Vauxhall Gardens. Lumen, 19, 69-88. https://doi.org/10.7202/1012316ar

Copyright (c) Canadian Society for Eighteenth-Century Studies / Sociéte canadienne d'étude du dix-huitième siècle, 2000
Ce document est protégé par la loi sur le droit d'auteur. L'utilisation des services d'Érudit (y compris la reproduction) est assujettie à sa politique d'utilisation que vous pouvez consulter en ligne.

https://apropos.erudit.org/fr/usagers/politique-dutilisation/ 


\section{Musical Nationalism and the Vauxhall Gardens}

During the Eighteenth Century, it was the custom for most theatres and concert halls in London to close from the late spring until the early fall months. It was during this time that the pleasure gardens of Vauxhall, Ranelagh (Raneleigh) and Marylebone (Marybone) became favourite spots for light entertainment in pleasant surroundings. The near twohundred year history of the Vauxhall Gardens (1661-1859) makes this location of particular interest. The gardens attracted visitors from all classes who came to enjoy the beauty of the illuminations and the varied musical entertainments that were presented nightly. The wonder and excitement of the place is recounted by Lydia Melford in Tobias Smollett's novel, The Expedition of Humphrey Clinker (1771):

Image to yourself my dear Letty, a spacious garden, part laid out in delightful walks, bounded with high hedges and trees, and paved with gravel; part exhibiting a wonderful assemblage of the most picturesque and striking objects, pavilions, lodges, groves, grottos, lawns, temples, and cascades; porticos, colonnades, and rotundas; adorned with pillars, statues and painting: the whole illuminated with an infinite number of lamps, disposed in different figures of suns, stars and constellations; the place crowded with the gayest company, ranging through those blissful shades, or supping in different lodges on cold collations, enlivened with mirth, freedom and good humour, and animated by an excellent band of musick. (92)

The gardens were located in the parish of Lambeth across the Thames river from Westminster, and about one and a half miles from the Westminster Bridge. The gardens opened to the public shortly after the Restoration. ${ }^{1}$ For the rest of the century, these 'Spring Gardens' constituted a place where someone might get the impression of a pleasant walk in the countryside, without the inconvenience of actually having to travel to the country itself. Such arcadian views of nature were rarely tempered by reality, but they were attractive to people. At Vauxhall, the elm trees were neatly laid out in straight rows, separated by sand walkways and manicured rose beds. Furthermore, refreshments were available upon 
demand (Coke [iv]). The location became a favourite haunt of Samuel Pepys, who recorded his first visit in his diary on 29 May 1662, and it is not uncommon to find Pepys making comments such as those from 23 June 1665: 'the ayre and pleasure of the garden, was a great refreshment to me, and, methinks, that which we ought to joy ourselves in.' His diary entry of 28 May 1667 records the attractions that were to remain a fixed element throughout the next century: good company, pleasant surroundings, music, and the singing of nightingales. Improvements were made to the property after Sir Samuel Morland obtained the lease in 1677 , and the gardens, which now covered some twelve acres of land, remained popular with Londoners until the early years of the next century, at which time interest began to wane.

The gardens would likely have remained a footnote in the social history of the Seventeenth Century had they not been leased to Jonathan Tyers in 1728. It was Tyers who had the vision to transform an area of pastoral beauty into an illusion of paradise with a diversity of pleasures for the senses (Edelstein 204). Tyers eventually became the sole proprietor of the gardens, which remained in the control of members of the family until the mid-Nineteenth Century. ${ }^{2}$ During the era of the Tyers family, the season at Vauxhall usually began in mid-May and lasted until early September. The gardens were open to the public in the evening after five p.m., except Sundays. A set admission fee was charged, and all who could afford this fee and were appropriately dressed were allowed to enter. If the degree to which the different social classes mixed is somewhat open to question, they were at least able to enjoy the same entertainments. ${ }^{3}$

One could access the gardens by boat from the Thames or by road. Until the Westminster Bridge was built in 1750, the land route was slow, as the narrow streets quickly became over-crowded with coaches. The river route was preferable, with ferries departing from both the Westminster and Whitehall Steps (Southworth 23-26). Landing at the Vauxhall Steps was not always without difficulty, however, and Lydia Melford's letter in Humphrey Clinker records an occasion which ended in violence. ${ }^{4}$

During the proprietorship of Jonathan Tyers, the main configuration of the gardens was established, consisting of two principal tree-lined avenues that ran the length of the property. These avenues intersected with several other paths and walkways that traversed partially or totally the width of the gardens (see Illustration No. 1 [opposite page], 'Aerial view of the Vauxhall Gardens, after plans from the 1790s'). ${ }^{5}$ This still left plenty of room for flower-covered arches, grottos, downs, pavilions and statues. Some fifty thousand torches and lamps illuminated the walkways and buildings, achieving the dual purpose of creating the fantasy- 

A "Orchestra"
B Statue of Handel
C Statue of Milton
D Entrance off Kennington Lane
E Cascade

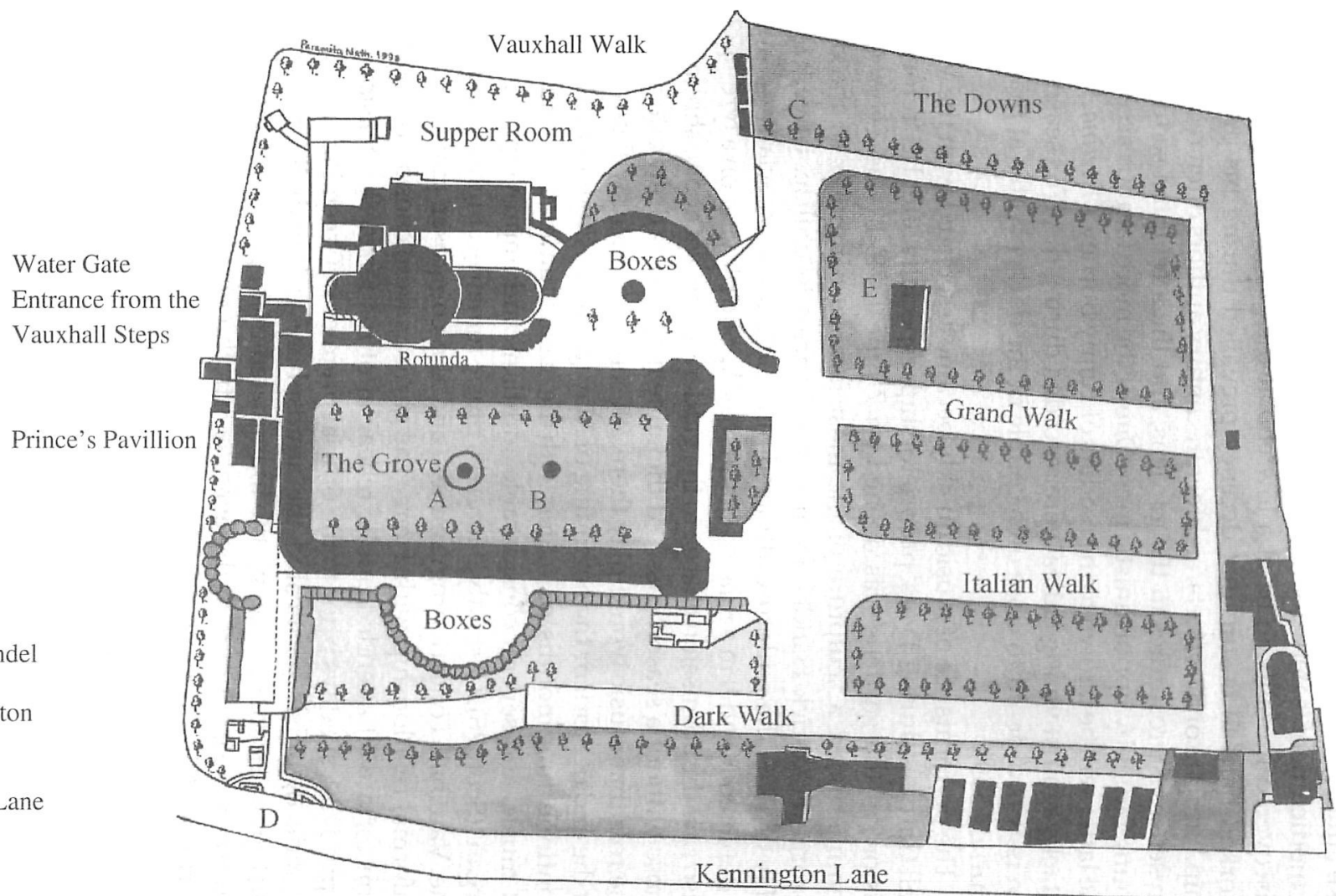

Illustration No. 1. Aerial view of the Vauxhall Gardens. 
like atmosphere for which the gardens were renowned, while ensuring a modicum of safety for the patrons, especially women. Tyers had discovered morality to be at a low ebb at the gardens in 1728, and he worked hard to ensure that decency prevailed during his proprietorship. ${ }^{6}$ In spite of his efforts, eighteenth-century authors often recount the presence of prostitutes in the gardens, and the attempted seduction of young ladies by opportunistic men. One of the more famous accounts of the latter will be known to the readers of Fanny Burney's Evelina. Several attacks against young ladies were recorded during the 1763 season, and Tyers was ordered to close off a couple of the darker walks at that time (Burney 559).

The performance of music quickly became associated with the Vauxhall Gardens during Tyers' proprietorship, especially after his 'reformed vision' of the gardens was opened on 7 June 1732. It was Tyers who commissioned a sculpture of the most famous composer of the day, George Frederick Handel, from Louis François Roubiliac. Unveiled in May of 1738 , the sculpture attracted much attention, especially because it depicted Handel in a relaxed manner as Apollo playing on a lyre. ${ }^{7} 1738$ also saw the admission charge to the gardens being set at one shilling for those without a season pass. ${ }^{8}$ At the same time, Tyers drew attention to the role that music would play there: 'the entertainment will be opened at the end of April or the beginning of May (as the weather permits), and continue three months, or longer, with the usual illuminations and bands of music, and several considerable additions and improvements to the organ' (Scott 26). Certainly, Handel's music remained highly popular in the Vauxhall concert programmes, and the composer maintained an informal relationship with Tyers. The gardens were chosen as the location for a well-attended public rehearsal of his Firework's Music on 21 April 1749, six days prior to the official premier in Green Park.

Indeed, music permeated the atmosphere at Vauxhall. It was the custom to promenade along the illuminated main paths and walkways during the early hours of the evening. Strolling bands of wind players performed impromptu serenades, most often consisting of arrangements of popular songs and opera arias. The gardens also contained ballrooms where couples danced, or went to escape a sudden shower of unexpected rain. One of the larger buildings on the grounds of the Vauxhall Gardens was The Rotunda, a structure capacious enough to house a large audience and the garden's orchestra when bad weather forced people indoors. When it was first opened, it was known as the New Music Room or Great Room (Southworth 44). Even when the weather was fine, music was still heard in the Rotunda, but was usually restricted to songs of a more popular nature. Such songs were often published as either single entities or in collections, and reached a wide 
audience. A typical example of this little-known repertoire is the song, 'Jenny of the Green,' which became very popular after Thomas Lowe used it to open the 1752 Vauxhall season (see Music Example No. 1). ${ }^{9}$ Later in the evening, most patrons moved to the area known as 'The Grove.' Here, a cold evening meal was available for purchase in the supper boxes or on tables located in 'The Grove' itself (McGairl 611). The serving of meals at Vauxhall was handled promptly; however, reports exist which complain of both high prices and meagre portions.

Also located in 'The Grove' was the focus of musical attention, an enormous outdoor bandstand which opened on 2 June 1735 (Edelstein 19). The Daily Advertiser commented on this building on the day of its opening.

There is built in the Grove of the Spring-Gardens at Vauxhall, an Octagon Temple, intended to serve as an Orchestra, for a Band of our finest Instrumental Performers; who will play (beginning at Five every Evening during the Summer Season) the compositions of Mr. Handel, and other celebrated Masters. ${ }^{10}$

This large, cylindrically-shaped structure dominated the landscape because of its height, and it housed the pipe organ mentioned earlier. The structure was enlarged in 1744 so that it could further accommodate an orchestra of some twenty-five musicians, as well as singers and instrumental soloists. ${ }^{11}$ It was here that a concert, usually lasting three hours, was performed. Initially, the concert began in the late hours of the afternoon, shortly after the gate opened. By the mid-Eighteenth Century, however, the concert began at 8.00 p.m. Even then, it appears that the most fashionable people only arrived after 9.00 p.m. There was never any problem hearing the music. The sides of this structure were open, and its height ensured that the music was heard throughout the Grove. While the concerts were transferred to other buildings on the grounds when the weather was particularly bad, there was little doubt that audiences of the day much preferred the outdoor setting. There, they could get as close or as far away from the music as they wished, partake of a meal, or stroll in the evening air.

One other structure, built near the grove with its 'Orchestra,' should be mentioned in conjunction with the performance of music at Vauxhall. The Prince's Pavilion was constructed for the use of Frederick, Prince of Wales (1707-51), who was not only a patron of the gardens but their titular landlord. This structure opened directly onto the road on one side and overlooked the Grove and Orchestra on the other. The Prince was a frequent visitor to Vauxhall and closely connected with much of its imagery. Since his continued patronage helped ensure Vauxhall's popularity, it was wise of Tyers to provide for Frederick's comfort. Yet, it 
would appear that Frederick's presence there brought with him other associations.

Firstly, the Prince was a music-lover, who played the cello with great dedication, although there are varying accounts of his prowess. Such was Frederick's interest in music that in 1733 he commissioned The Music Party (a portrait attributed to Philippe Mercier) of the Prince of Wales playing the 'cello, accompanied by his sisters. ${ }^{12}$ Given that music was a fixed point of interest in Frederick's life, it should come as no surprise that he was much drawn to the musical programmes given at Vauxhall. Secondly, Frederick was the centre of unusual political attention as the Prince of Wales. He was openly despised by his parents, King George II and Queen Caroline. His mother is on record as having stated at one point that she hoped that she would never see 'the monster's face again,' while Frederick's equally loving father was of the opinion that Frederick was 'the greatest villain that ever was born' (De-La-Noy 161). As a symbol of their affection for their first-born son, the king and queen had Frederick, his wife and their new-born daughter expelled from court in 1737. The nobility were instructed that Frederick was to be treated as a pariah, and not to be received in their homes. The alienated Frederick, however, was quickly adopted by the political forces who opposed the Hanoverian rule of his father. As Michael Burden points out, 'there are two ways of achieving a revival of a state. One is the occurrence of a major event such as a revolution, out of which can emerge either a tyranny or a just monarchy. The other is by the actions and example of a patriot king' (Burden 16). The forces of opposition to the Hanoverian rule saw the wisdom of attempting to design circumstances that would lead to the latter situation.

Frederick became a convenient symbol for individuals such as Lord Bolingbroke and Alexander Pope who actively sought a new political order for England. Frederick's banishment from court came just one year before Bolingbroke set down his liberal ideology in The Idea of a Patriot King. The work's first authorized publication came in 1749, carrying a dedication to Frederick (De-La-Noy 178). Bolingbroke's thesis rested on a naive and altruistic sense of patriotism, with Frederick as the focus of his ideas. As T.J. Edelstein points out, Frederick became 'the symbolic head of the Opposition. As such, he became the embodiment of the Opposition's ideal of a Patriot King.... The perception of this humanist Patriot King as one who would restore the political and social balance to true principles and liberty through his own moral example was an idea sympathetic to the central themes at Vauxhall' (Edelstein 213).

Nationalistic and patriotic ideals spilled over into the area of musical performance, especially after 1745 when Tyers contracted the English composer, Thomas Arne (1710-78), to introduce vocal music to the 
Vauxhall concerts. This was somewhat novel at the time for there were few places where secular, vocal music (set to English texts) of artistic merit could be heard. Arne's political sympathies have not been documented in detail; however, his career appears to have been supported by Frederick, who commissioned Arne's English opera, Alfred, for performance at his residence of Clivedon in 1740 (Alexander Scott Xv). Seemingly, the stirring, patriotic ode, 'Rule Britannia,' was placed at the end of the opera, especially to please the Prince of Wales. This was the first music from the opera to be published, and it was performed regularly in the Vauxhall Gardens thereafter whenever patriotic sentiments were appropriate (see Music Example No. 2). While Arne also composed for the other London pleasure gardens, his association with Vauxhall proved to be highly significant in his career. Arne composed no less than two hundred songs for the pleasure gardens, and the twenty collections of his songs that were published in his lifetime did much to revive the popularity of English song in the Eighteenth Century. ${ }^{13}$ By 1755, Arne felt confident enough in this area to publish his Six Cantatas For a Voice and Instruments in full score rather than in the much cheaper keyboard format. These extended works are indicative of the role that English vocal music played in the Vauxhall concerts. Tuneful and direct in their expression, these cantatas bridged the gap between art music and more popular styles with complete ease.

Arne's influence on the subsequent direction of the concert programming at Vauxhall should not be underestimated. In addition to introducing solo vocal music set to English texts to the concerts, Arne helped establish Vauxhall as a place where the concert music of British composers might be given professional performances, an opportunity often denied to them in London. Much of the success of the Vauxhall concerts was the result of the high levels of professionalism of the performers. The orchestra was made up of the best performers drawn from the London theatres and concert societies. These musicians must have appreciated the opportunity to continue working during the summer months, a time when their normal sources of revenue vanished. Contemporary accounts often remark on the high standards of execution. As Charles Cudworth notes, 'the Vauxhall "band" was indeed probably one of the very few professional ensembles, outside the theatres, which existed on a fairly permanent basis...' (Cudworth 27). Leadership of the orchestra was a highly prestigious and sought-after post, and one that was open to the best available violinist, be he British or Continental in origin.

For most of the Eighteenth Century, the responsibilities attendant on being orchestra leader included the selection of music to be performed. For a violinist such as John Abraham Fisher (1744-1806), who also had 
aspirations to compose concert music, leading the Vauxhall orchestra gave him the opportunity to have his six symphonies performed under professional conditions. ${ }^{14}$ Having music performed at Vauxhall increased its prestige, and publishers took advantage of this fact by mentioning the association on the title pages of publications. Even foreign-born composers, such as Johann Christian Bach (1735-82), realized that success at Vauxhall meant the likelihood of increased sales of their music. In the case of Bach, four collections of songs which proudly bore the name of Vauxhall were eventually produced. ${ }^{15}$ Yet, the concert experience at Vauxhall differed greatly from those found in the winter concerts in London. To demonstrate this difference, it will be useful to summarize the various musical activities and venues in London during the fall and winter months.

The development of public concerts in London predates those on the continent by some fifty years. John Banister organized public concerts at his Whitefriars School as early as 1672 , to be followed by Thomas Britton's series (1678-1714), held in a loft above his Clerkenwell shop. ${ }^{16}$ The subsequent growth of public concerts was likely due to the fact that the English monarchy did not provide the kind of strong artistic leadership that was found in absolutist courts on the continent. Without such leadership, musicians 'began to shift their attention away from the court to the wealthy homes and public places of London' (Weber [1989] 293-84). This resulted in a much accelerated pace in the development of London's musical life, not only in the area of public and private concerts but also in the range of theatrical presentations utilizing music. Indeed, by the beginning of the last decade of the Eighteenth Century, contemporary reports often speak of the 'rage for music' that gripped the city. ${ }^{17}$ Throughout the second half of the Eighteenth Century, London provided musical opportunities that few other cities could match. Yet it was a hard life, and musicians were forced to develop entrepreneurial skills that were rarely necessary in court-dominated environments. As Simon McVeigh notes, 'for all but the foreign élite, entry into London's concert life was achieved only by arduous struggle; and for most musicians the struggle for material prosperity and for advancement within the profession continued to the end of their lives' (McVeigh 182).

Table No.1 provides a brief outline of musical activities in London up to the period of the early 1790s. It is an impressive list to be sure, and the offerings of societies such as The Professional Concerts were of the highest possible calibre. ${ }^{18}$ Examination of this list reveals that there were likely more opportunities for British performers than there were for British composers. While it was relatively easy for an instrumentalist of professional calibre to get a position playing in one of the theatre orchestras or to freelance in the various concert series, the choices were 
far fewer for native-born composers, especially those who aspired to write opera or instrumental music.

The King's Theatre presented Italian operas, and only those by continental composers. The concerts of both the Academy of Ancient Music and The Concert of Ancient Music are representative of the cult for older music in Britain. The most recent music to be heard in these concerts was at least twenty years old, while much of the repertoire came from the Elizabethan period. Several of the remaining concert societies were devoted to the performance of short, and frequently unaccompanied, vocal works. Of the regular, public-concert series held during the fall and winter months, only the Bach/Abel concerts (to be followed by The Professional Concerts and the Pantheon concerts) presented instrumental music on a regular basis. The choices open to an aspiring English composer of instrumental music or large-scale, accompanied vocal music, then, were very limited. A further complication lay in the fact that the social hierarchy of concert life in London led the wealthy upper class towards foreign musicians and composers.

An assessment of this social hierarchy can be found in The Morning Post, for 21 January 1789.

The HANOVER-SQUARE [Professional Concert] - QUALITY.
The TOTTENHAM-STREET [Concert of Ancient Music] - GENTRY.
The FREEMASONS'-HALL [Academy of Ancient Music] - PEOPLE.
And the ANACREONTIC [Society] - FOLKS.

(McVeigh 11)

Had such a notice been printed twenty years earlier, there would likely have been few changes. The reference to the Hanover Square concerts would have been to the Bach/Abel series (defunct by 1789), and any possible mention of the concerts at the Pantheon would have been only slightly lower on the social scale. The pricing of tickets further restricted the various concerts according to class. As early as 1765 , the cost of a subscription to the Bach/Abel concerts was five guineas, an amount that ensured their exclusivity. The attraction of the Bach/Abel concerts was not only the high calibre of the performances but also the inclusion of the latest continental music and the most prestigious foreign soloists on the programmes. Even the performance of Italian opera, usually given before a socially-diverse audience on the continent, was largely preserved for the upper classes at the King's Theatre in London. This was accomplished by having few cheap seats in the theatre's gallery (Weber [1989] 303-04). Thus, the association of foreign art with the tastes of the wealthy, upper class became a recurring theme in the musical life of London. The result was that there were few opportunities for British composers who wished to compose serious concert music. The exception 
to this unfortunate situation was to be found in the pleasure gardens, and at Vauxhall in particular.

Unfortunately, details of the Vauxhall concert programmes are very sketchy until the late years of the Eighteenth Century. Archival records from the gardens themselves dealing with the music performed there appear to be lost except for the period of 1790-93, and even these are not complete. The actual listing of the works to be performed was not included in newspaper advertisements until $1786 .{ }^{19}$ There appears to have been no prior need to undertake such expensive advertising since audience attendance at the gardens does not appear to have been driven by the content of the concert programmes. Certainly, Londoners were assured of high quality performances regardless of the day they attended. The actual format of the concerts was established in the 1740s and consisted of a programme which was divided into two 'Acts'. The concerts themselves were lengthy, lasting three hours or longer. In the 1786 season, each concert consisted of approximately fifteen items. Instrumental music alternated with vocal music, with the more 'serious' works usually reserved for the first 'Act.' It was common to find two concertos on the programme (one usually being an organ concerto), a symphony, and an overture. These purely instrumental works alternated with cantatas and songs of a lighter nature, and the concert usually ended with some form of vocal ensemble. One interesting aspect of these programmes is that they contained a mixture of older and the most up-to-date music. Handel's music remained popular, as did that of Thomas Arne, George Rush, C.F. Abel, J.C. Bach, J. Stamitz, and J.C. Smith, even though several of these composers had been dead for many years. The symphonies of Haydn were well known to Vauxhall audiences even before the first of the composer's two enormously popular visits to London. During the 1790 season, one and sometimes two symphonies by Haydn were performed each evening (Cudworth 28)!

The surviving concert programmes at Vauxhall demonstrate a sense of balance, with British musicians and British music being given equal billing with foreign art. This has led Charles Cudworth to observe that 'Vauxhall was one place where English orchestral music had at least a fair chance of a hearing, beside the otherwise all-conquering foreigners' (Cudworth 27). During the last quarter of the Eighteenth Century, it was the British-born James Hook (1746-1827) who organized the concerts. Hook was given the appointments of organist, resident composer, and music director at Vauxhall in 1774 . He retained these posts until 1820, a remarkable tenure of forty-six years! If he played an organ concerto every night of each summer season, as has been reported, Hook must have performed on the Vauxhall organ more than 5,000 times! ${ }^{20}$ He was a prolific song composer, with more than 2000 examples of the genre to 
his credit. He is accorded with having kept 'the door open' at Vauxhall for British-born composers and performers, giving them opportunities that they were often denied in the exclusive winter concert series in London. Perhaps because of this and the degree to which Hook's music dominated the Vauxhall programmes, he was much criticised by foreign musicians resident in London.

Table 2 gives a representative example of programmes from the 1787 Vauxhall season, that of 14 July. This programme is typical of the surviving documentation of the concerts at Vauxhall in that the various symphonies are not differentiated by either number or key designation, thus making it almost impossible in most cases to identify individual works. Seemingly of greater importance were the names of the various performers who would appear. While Hook's vocal music came to dominate that part of the concert programmes, the music of other British composers continued to be heard throughout the season. Indeed, twelve out of the twenty-six composers of symphonic music heard during the 1790 Vauxhall season were either British or had careers based in Britain. ${ }^{21}$ While this statistic does not take into account the number of works performed by each composer, it would appear to indicate that Vauxhall still welcomed the works of British composers late in the century, and saw the need to continue performing their music.

Yet names such a Fisher, Rush, Hook, Linley and Brooks were all-butforgotten by the middle years of the Nineteenth Century. ${ }^{22}$ Why did the music of these composers languish? Was it because it did not compare in quality with the music of the continental composers? This does not seem tenable, given the quality of works such as James Brooks's Concerto No. 1 in D major for violin and orchestra and Arne's keyboard concerti. ${ }^{23}$ Nor would the vocal music of the period seem to suffer from any comparisons to continental composers. Works such as the cantata, Awake, my lyre and the series of Elegies composed by Thomas Linley (the elder) demonstrate craftsmanship of the highest order and an immediate melodic appeal. ${ }^{24}$ Surely it is not the quality of such music that was a problem, but only that it was not performed often enough to give it a widely-based audience. While the concerts at Vauxhall assisted in giving British composers a venue for their music, the effect of only one such venue was ultimately limited. With music of such quality largely lying fallow, it could only be hoped that the nascent revival of British music, such as that heard at Vauxhall, would be cultivated and nurtured in the next century.

PAUL F. RICE

Memorial University of Newfoundland 


\section{Notes}

1 The entry in Evelyn's Diary for 2 July 1661 speaks of the area as the 'new Spring Gardens at Lambeth, a pretty-contrived plantation' (cited by W. A. Scott, Green Retreats, p. 18). In this period, the area was also referred to as Fox-Hall by some.

2 Following Jonathan Tyers' death in 1767, the control of the gardens passed on to his sons, Thomas and Jonathan Junior. Thomas sold his share to his brother in 1785. The latter acted as sole proprietor until his death in 1792. See W. A. Scott, Green Retreats, pp. 25-28.

3 As McVeigh points out, 'social boundaries were ... blurred at the summer garden concerts,' often to the surprise of foreign visitors (Concert life in London from Mozart to Haydn, p. 39). Even given this situation, there was still a hierarchy in the social ranking of the various pleasure gardens. Ranelagh (which charged the highest admission price) was considered to be the most exclusive, followed by Vauxhall and Marylebone. Neither Ranelagh nor Marylebone, however, enjoyed the kind of financial or social stability that Vauxhall was able to demonstrate throughout the Eighteenth Century. 'It [Vauxhall] maintained a subtle mix of gentility with a hint of freedom, of popular entertainment with elegance and class, of reality with a magical dream-world': (McVeigh, p. 44).

4 'A parcel of ugly-looking fellows came running into the water, and laid hold on our boat with great violence, to pull it ashore; nor would they quit their hold till my brother struck one of them over the head with his cane': (Humphrey Clinker, $\mathrm{p}$. 91.).

5 I am indebted to Ms. Paramita Nath for the creation of this drawing. I am further indebted to Ms. Elizabeth Zedel for the computer processing of Ms. Nath's sketch.

6 This appears to have been a problem even in Pepys' era, as his diary entry from 27 July 1667 records.

7 Edelstein, pp. 204-05. It was also at this time that the architecture of the buildings at the gardens began to move away from classical ideas to those which reflected the tastes of the Prince of Wales: exotic designs, chinoiserie, and Gothic revival. See Coke, [vi].

8 The admission was raised to two shillings only in 1792 .

9 I am much indebted to Professor Ursula Rempel of the School of Music, The University of Manitoba, for providing me with the source material from her own collection for the music examples in this paper.

10 Cited by McGairl, p. 611. See also Cudworth, p. 29.

11 This estimation is based on Cudworth's research into the surviving part books for some works by James Hook, now housed in the University Library at Cambridge (Cudworth, pp. 26-27). Unfortunately, the iconographic evidence from the period rarely shows the complete 'Orchestra,' or in sufficient detail to make sound judgements in this area.

12 De-La-Noy, p. 107. Three versions of the painting exist, two set outside, and one set inside the Banqueting House at Hampton Court Palace. A reproduction of one of the 'outdoor' versions of the painting can be found in Anderson's chapter, 'Music,' in Eighteenth-Century Britain, p. 292.

13 Highfill et al, A Biographical Dictionary ..., s.v. 'Arne, Thomas Augustine.' 
14 These works were published (in performing parts only) in 1772, their title pages bearing the inscription 'as performed at Vauxhall.' All six symphonies have been edited by the present author for future publication.

15 McGairl, p. 612. Similarly for soloists (and singers in particular), references to performances at Vauxhall helped careers.

16 McVeigh, pp. 3-4. Public concerts in Paris began only as late as 1725 with the formation of the Concerts Spirituels.

17 The Morning Chronicle (1 April 1788) speaks of 'the present increasing rage for Musick.... There are concerts in every part of the town,' (cited by McVeigh, Concert life, p. 1).

18 The Professional Concert was organized in 1785 by Wilhelm Cramer as a co-operative venture. By 1787 , this organization had received much recognition and was felt by many to have surpassed even the Bach/Abel concerts: (McVeigh, Concert Life, p. 17.) Aspects of the audiences and various concert societies have been examined by William Weber in The Rise of Musical Classics in Eighteenth-Century England (Oxford: Clarendon, 1992).

19 On 29 May 1786, three days before the official opening of the season, Tyers held a commemorative celebration, called the Vauxhall Jubilee. For the occasion, Tyers had extensive refurbishing undertaken of buildings such as the Orchestra and the Rotunda. Two new ballrooms were erected and an additional 15,000 lamps were installed in the gardens. This celebration met with much critical success, and Tyers subsequently advertised the full details of sixty-seven of the concert programmes which were given in the 'Jubilee' season. These advertisements, along with the archival material from 1790-93, provide an accurate image of not only the works that were performed but also the role that British composers and performers played in the garden concerts.

20 Roger Fiske, p. 395. Fiske gives the date of Hook's appointment as 1775.

21 Based on documentation found in Cudworth, 'The Vauxhall Lists,' pp. 40-1.

22 The recent publication of scores and recordings of the music by some of these composers may help to change this situation. Examples of the renewed interest in British music on home soil can be seen in the series scores published under the rubric of Musica Britannica, and the recordings released on the Hyperion label in its series, The English Orpheus.

23 Hyperion recordings, CDA66865 and CDA66435 respectively.

24 Hyperion CDA66698. 


\section{Table No. 1}

\section{Music in London up to $c .1790$}

1) Theatres:

a) King's Theatre, Haymarket, site of Italian opera performances;

b) Drury Lane Theatre, and Theatre Royal, Covent Garden, sites of opera and semi-opera performances in English, pantomime, and plays with incidental music;

2) Concert Series:

a) Castle Concerts (at Castle tavern, begun in 1715), diminished in importance by 1780 ;

b) Academy of Ancient Music (begun in 1726), concerts devoted to the music of earlier composers; its importance diminished after 1752 until it was turned into a public concert series along the lines of the Bach/Abel concerts in the 1780s;

c) Madrigal Society (begun in 1741), devoted to the performance of vocal music; originally the members were of humble origins, although the society began to attract the interest of the upper classes later in the century;

d) Catch Club (begun in 1761), devoted to the composition and performance of catches, glees, and canons;

e) Bach/Abel Concerts (begun in 1765), quickly became London's most prestigious concert series, attracting a largely aristocratic audience; concerts were devoted to music by foreign composers, most often German, Italian or French. This series faced serious competition after 1774 from the Pantheon concerts. J.C. Bach died in 1782, and the Earl of Abingdon continued the concerts until 1784;

f) Professional Concerts (begun 1785), a re-organization of the Bach/Abel concerts which usually presented 12 concerts in winter months in Hanover Square, and were considered to be highly prestigious; foreign music, especially that of Haydn, figured prominently in the programmes;

g) Anacreontic Society (begun in 1766), concerts originally devoted to vocal works; orchestral works added to programmes in the 1780s;

h) Pantheon Concerts (begun 1774), in direct opposition to the Bach/Abel concerts, these concerts featured Italian music and, occasionally, some English music;

i) Concert of Ancient Music (begun in 1776), concerts of music more than twenty years old; inspired the famous Handel 
festivals during the 1780s and 1790s; often attracted high ranking members of the nobility;

3) Other Concerts:

a) Oratorio concerts, presented in the London theatres each year during Lent;

b) Benefit concerts, presented for the benefit of individuals, but most often in conjunction with established concert series;

c) Masonic lodges; several such as the Lodge of the Nine Muses, Somerset House Lodge, Pilgrim Lodge, and the United Grand Lodge had long standing musical traditions.

Table No. 2

Vauxhall Concert Programme of 14 July 1787

\section{Act I}

Full Overture,

[K.F.] Abel

Overture to The Syrens,

Song, (sung by Mr. Incledon),

Symphony,

Overture to Berenice, [J. A.] Fisher

[Thomas] Shaw

Song, (Miss Bertles),

[G.F.] Handel

Symphony,

Organ Concerto,

Song, (Miss Leary),

[F.J.] Haydn

Song, (Miss Leary),

Act II

Song, (Mr. Incledon),

Webb

Glee,

J.] Hook

Song, (Miss Bertles),

The Queen of May,

[J.] Hook

[The above is found in London newspapers for that day. It is likely that the organ concerto and many of the songs were by Hook.] 
84 Paul F. Rice

Music Example No. 1

"Jenny of the Green"

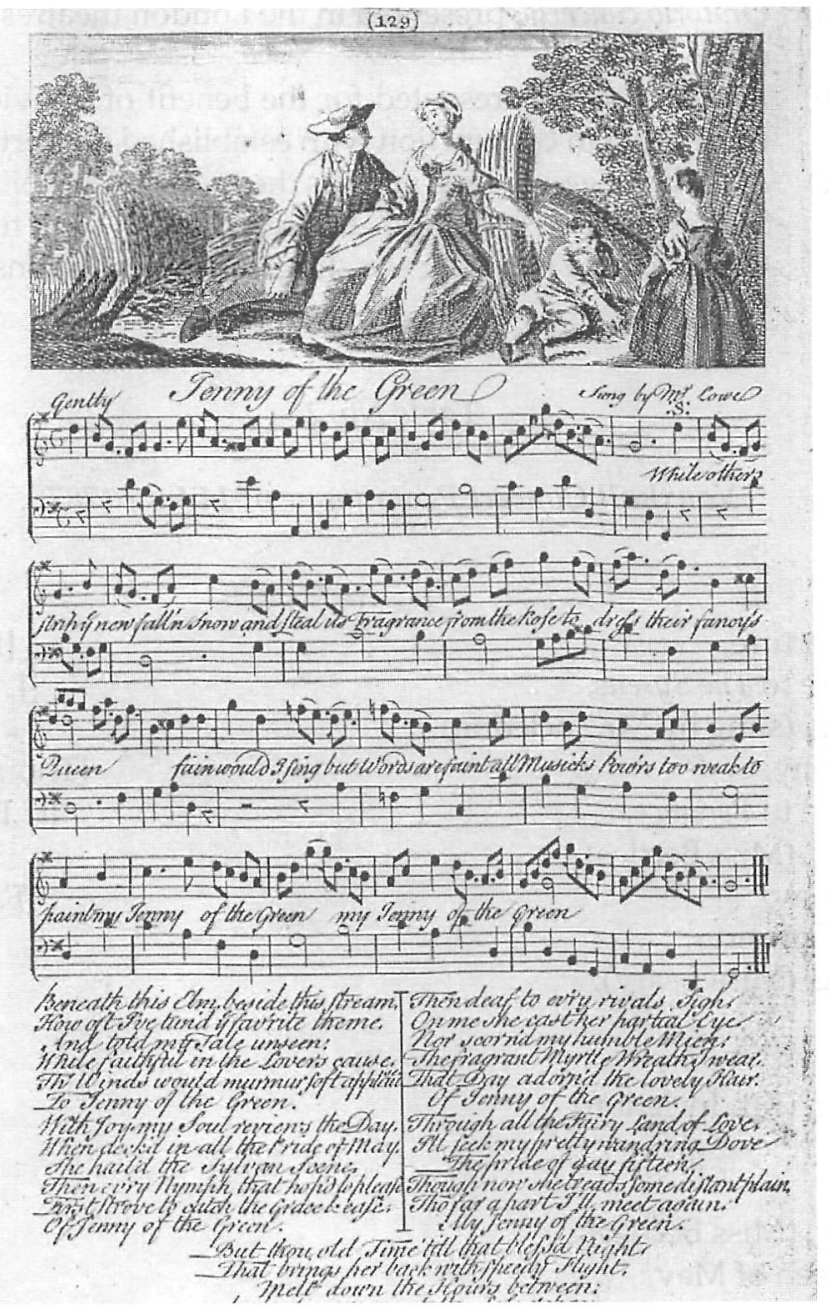


Music Example No. 2

Thomas Arne, Alfred, "Rule Britannia"

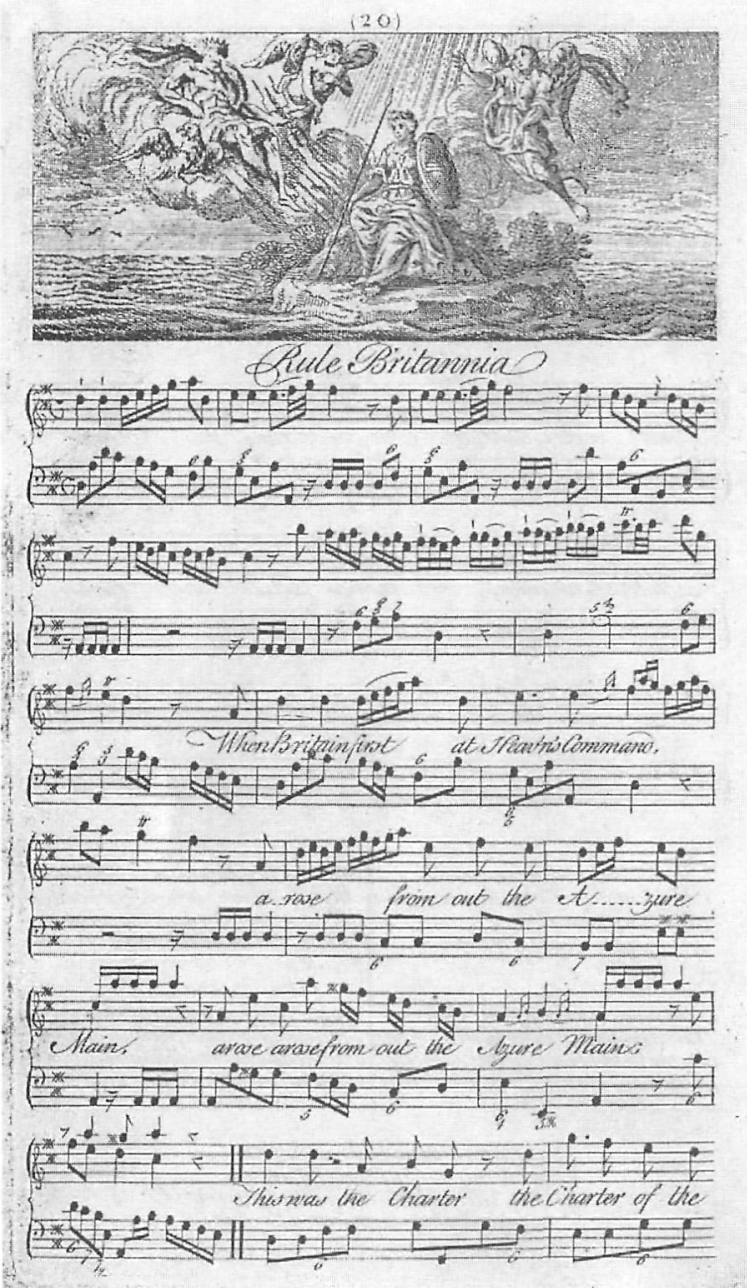


Music Example No. 2, (cont.)

Thomas Arne, Alfred, "Rule Britannia"

(21)

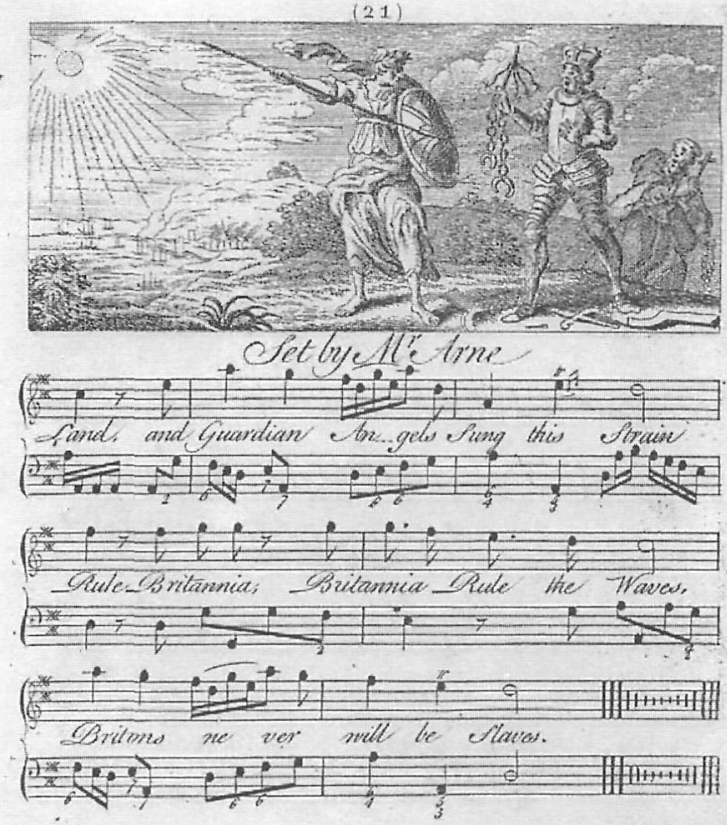

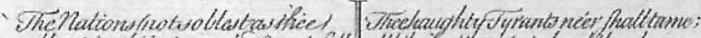

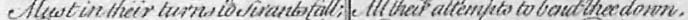

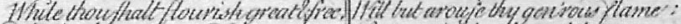

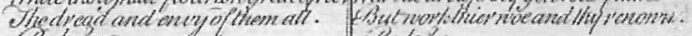
Shuteces:

$$
\text { o }
$$

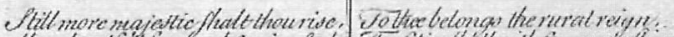

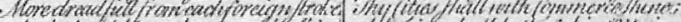

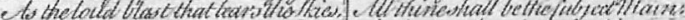

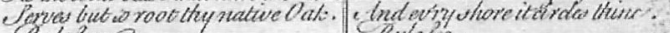
Riulebre? Ciuletir.

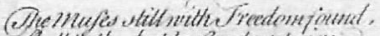

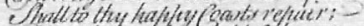

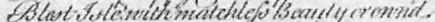

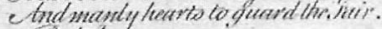
truege. 


\section{Bibliography}

Anderson, Nicholas. 'Music.' Eighteenth-Century Britain, The Cambridge Cultural History of Britain, vol 5, ed. Boris Ford. Cambridge: CUP, 1992.

Burden, Michael. Garrick, Arne and the Masque of Alfred: A Case Study in National Theatrical and Musical Politics. Lewiston, Queenston and Lampeter: The Edwin Mellen Press, 1994.

Burney, Frances. Evelina or The History of A Young Lady's Entrance into the World, ed. Sir Frank D. MacKinnon. Oxford: Clarendon, 1930.

Coke, David. The Muse's Bower: Vauxhall Gardens, 17228-1786. Sudbury, Suffolk: Gainsborough's House, 1978.

Cudworth, C.L. 'The Vauxhall “Lists.”' The Galpin Society Journal 20 (March, 1967): 24-42.

De-La-Noy, Michael. The King Who Never Was: The Story of Frederick, Prince of Wales. London: Peter Owen Publishers, 1995.

Edelstein, T.J., and Brian Allen. Vauxhall Gardens. New Haven, Connecticut: Yale Center for British Art, 1983.

Edelstein, T.J. 'Vauxhall Gardens.' Eighteenth-Century Britain, The Cambridge Cultural History of Britain, vol 5, ed. by Boris Ford. Cambridge: CUP, 1992.

Fiske, Roger. English Theatre Music in the Eighteenth Century, rev. ed. London: OUP, 1986.

Highfill, Jr., Philip H., Kalman A. Burnim, and Edward A. Langhans. A Biographical Dictionary of Actors, Actresses, Musicians, Dancers, Managers $\mathcal{E}$ Other Stage Personnel in London: 1660-1800. Carbondale \& Edwardsville: Southern Illinois UP, 1973-93.

McGairl, Pamela. 'The Vauxhall Jubilee, 1786.' The Musical Times 127/1726 (November, 1986): 611-15.

McVeigh, Simon. Concert life in London from Mozart to Haydn. Cambridge: CUP, 1993.

The New Grove Dictionary of Music and Musicians, 6th ed., ed. Stanley Sadie, s.v. 'Hook, James,' by Charles Cudworth.

Pepys, Samuel. The Diary of Samuel Pepys, ed. Henry B. Wheatley, 10 vols. 1893-99. New York: AMS Press, 1968.

Rice, Paul F. An Edited Collection of the Theatre Music of John Abraham Fisher. Studies in the History and Interpretation of Music 48. Lewiston, Queenston \& Lampeter: The Edwin Mellen Press, 1996.

Scott, Alexander. Introduction to Alfred by Thomas Augustine Arne, Musica Britannica 47. London: Stainer and Bell, 1981.

Scott, W.A. Green Retreats; The Story of Vauxhall Gardens: 1661-1859. Long Acre, London: Odhams Press Limited, 1955.

Smollett, Tobias. The Expedition of Humphrey Clinker, Text ed. O.M. Brack, Jr., with an Introduction and Notes by Thomas R. Preston. Athens, Georgia: U of Georgia P, 1990.

Southworth, James Granville. Vauxhall Gardens: A Chapter in the Social History of England. New York: Columbia UP, 1941. 


\section{Paul F. Rice}

Weber, William. 'London: a City of Unrivalled Riches,' The Classical Era from the 1740s to the end of the 18th century, ed. Neal Zaslaw, Man \& Music/Music and Society 6. Englewood Cliffs, NJ: Prentice Hall Inc., 1989.

. The Rise of Musical Classics in Eighteenth-Century England. Oxford: Clarendon, 1992.

The Vauxhall Gardens Archive [drawn from contents of the Minet Library, London], Emmett Publications, n.d. 